\title{
Hastane Yapıları Teknik ve Destek Hizmet Birimlerinin Mekânsal Büyüklük Analizi: Çukurova Üniversitesi Tıp Fakültesi Balcalı Hastanesi Örneği
}

\author{
Yelda DURGUN ŞAHIN ${ }^{* 1}$
}

\author{
${ }^{1}$ Çukurova Üniversitesi, Mimarlık Fakültesi, Peyzaj Mimarlığı Bölümü, Adana
}

Geliş tarihi: 03.10.2019 Kabul tarihi: 20.12.2019

\section{$\ddot{O} z$}

Hastaneler büyük, karmaşık ve 24 saat kesintisiz sağlık hizmeti sağlayan yapılardır. Bu yapıların kesintisiz çalışmasında teknik ve destek hizmet birimleri önemli rol almaktadır. Bu birimlerde ortaya çıacak aksamalar, hasta, hasta yakını ve personel güvenliğini tehlikeye atmakta, ortam konforlarının bozulmasını sağlamakta hatta hastalarda ölümle sonuçlanabilecek ciddi sonuçlar doğurabilmektedir. Bu doğrultuda böylesi öneme sahip olan teknik hizmet birimlerine dikkat çekmek amacıyla bu çalışmada Çukurova Üniversitesi Tıp Fakültesi Balcalı Hastanesi'nde yer alan teknik ve destek hizmet birimlerinin mekânsal büyüklüklerinin belirlenmesi amaçlanmıştır. Araştırmanın temel materyalleri, Balcalı Hastanesi 1/1.000 ölçekli hâlihazır haritası, 1/100 ölçekli mimari kat planları ve hastane yapısına yönelik saha tespit çalışmalarından elde edilen niceliksel ve niteliksel verilerinden oluşmaktadır. Araștırmanın yöntem kurgusu, hastane toplam kapalı alan nicel verileri ile teknik ve destek hizmet birimlerinin nicel verilerinin alansal büyüklük çerçevesinde irdelenmesine dayanmaktadır. Bu doğrultuda yapılan bu çalışmada, hastanenin toplam mekânsal büyüklüğü ile teknik ve destek hizmet birimlerinin mekânsal büyüklükleri belirlenmiştir. Ç.Ü. Tıp Fakültesi Balcalı Hastanesi örneği konulu araştırmada mekânsal büyüklükler Türkiye Sağlık Yapıları Asgari Tasarım Standartları 2010 Y1lı Kılavuzunda yer alan standartlar çerçevesinde incelenerek değerlendirilmiş ve araştırmanın sonucunda teknik birimlerin, hastanenin toplam kapalı alanının yaklaşık \%10'unu oluşturduğu görülmüştür. Ayrıca asgari standartlar doğrultusunda, 1200 yataklı hastaneler için belirlenmiş olan, yatak başına asgari $130 \mathrm{~m}^{2}$ mekânsal alan büyüklüğ̈nnün, Balcalı hastanesinde bu değerin üzerinde olduğu ve yatak başına yaklaşık $159 \mathrm{~m}^{2}$ alan kullanıldığı tespit edilmiştir.

$\mathrm{Bu}$ çalışma ile hastane tasarımlarında ön planda tutulan mimari konfor şartlarının ve estetik düzeyin yanısıra, sisteme can veren teknik ve destek hizmet bölümlerinin önemine dikkat çekmek istenmiştir.

Anahtar kelime: Hastane yapısı, Mekânsal büyüklük analizi, Teknik ve destek hizmet birimleri

\footnotetext{
"Sorumlu yazar (Corresponding author): Yelda DURGUN ŞAHIN, ydurgunsahin@cu.edu.tr
} 


\title{
Spatial Size Analysis of Technical and Support Service Units of Hospital Buildings: A Case of Çukurova University Medicine Faculty Balcalı Hospital
}

\begin{abstract}
Hospitals are large, complex buildings that provide 24-hour uninterrupted health care. Technical and support service units play an important role in the uninterrupted operation of these buildings. Disruptions in these units jeopardize the safety of patients, relatives and personnel, cause deterioration of the comfort of the environment and may even have serious consequences that may result in death in patients. In this direction, in order to draw attention to such technical service units; The aim of this study was to determine the spatial size of technical and support service units located in Balcalı Hospital of Çukurova University Faculty of Medicine. The main materials of the study consist of Balcali Hospital 1/1.000 scale current map, 1/100 scale architectural floor plans and quantitative and qualitative data obtained from field determination studies for the hospital structure. The methodology of the research is based on the examination of the total indoor area quantitative data of the hospital and the quantitative data of the technical and support service units within the framework of the spatial magnitude. In this study, the total spatial size of the hospital and the spatial size of the technical and support service units were determined. C.U. Medicine Faculty Balcalı Hospital instance of spatial size of Turkey Ministry of Health on research evaluated by examining the health standards in 2010 and the results of the research of the technical units of the hospital's total covered area were found to constitute approximately $10 \%$. In addition, in accordance with the 2010 Health Standards of the Ministry of Health, it was determined that the hospital has an area of at least $130 \mathrm{~m}^{2}$ per bed and $1200 \mathrm{~m}^{2}$ per bed.
\end{abstract}

With this study, it is aimed to draw attention to the importance of architectural comfort conditions and aesthetic level which are given priority in hospital designs, as well as technical and support service departments that give life to the system.

Keywords: Hospital structure, Spatial size analysis, Technical and support services

\section{GİRİS}

Sağlık sistemleri geçmişten günümüze kadar geçen süreçte dönemin şartlarına göre sağlık hizmetlerini sürdürmüş ve sürdürmeye de devam etmektedir. Sağlık sistemlerinin sunulduğu yapılar olan hastaneler, süreç içinde dünyadaki teknolojik gelişmeler, sağlık endüstrisindeki ilerlemeler, nüfusun artması, yaşam süresinin uzaması, standartlardaki değişimlerin mekâna yansıması gibi nedenlerle değişim geçirmekte ve yeni mekân ihtiyaçları ile yeniden şekillenmektedir.

Dünyada bilgiye verilen önem ile paralel olarak tıp alanında da yenilikler gerçekleşmektedir. Sağlık yapılarının mekânsal konfor standartlarına, yapay ışık, havalandırma, malzeme ve bakım birimleri gibi kullanıcıların konfor düzeylerini artıracak teknik destek birimleri eklenmiş ve bu gelişmelere yönelik yeni planlamalara yer verilmiştir. Geçmişten günümüze kadar yaşanan teknolojik gelişmeler hastane yapılarının da tasarımlarını değiştirmekte olduğu gözlenmektedir [1].

Yaşanan teknolojik gelişmelere paralel olarak Balcalı Hastanesi de ilk kurulduğu mekânsal büyüklük ve mekânsal konfor şartlarında kalmayarak, birçok bölümde hızla standartlara uyum sürecine adapte olmakta hatta yeni ek binalarla mekânsal büyüme yaşamaktadır.

$\mathrm{Bu}$ çalışmada, bir hastane yapısında yer alan Teknik Hizmet bölümlerinin mekânsal büyüklüğü ile hastanenin toplam kullanım alanı içerisindeki yerinin, örneklem alanı olan Balcalı Hastane yapısı üzerinde incelenmesini kapsamaktadır. Bu tür yapiların analizinde öncelikle hastanenin 
özelliğinin belirlenmesi gerekmektedir. $\mathrm{Bu}$ doğrultuda öncelikle Balcalı Hastanesi ile ilgili genel bilgilere yer verilmiştir.

\subsection{Balcalı Hastanesi Genel Bilgiler}

Çukurova Üniversitesi Tıp Fakültesi Balcalı Hastanesi Adana İli Sarıçam İlçesi'nde yer almakta ve şehrin kuzey bölgesinde kuzey-güney doğrultusunda konumlanmaktadır. Hastane binasının yapımına 1985 yılında başlanmış olup, yap1 1987 yılında hizmete açılmıştır. Hastane çevre düzenlemesiyle birlikte $95.000 \mathrm{~m}^{2}$ açık alan üzerine kurulmuş ve toplam kapalı alanı yaklaşık $190.651 \mathrm{~m}^{2}$ den oluşmaktadır.

Hastane, yaklaşık 1200 yatak kapasiteli, günde ortalama 2100 hastaya hizmet veren Sağlık Bakanlığı'na bağlı 3. Basamak bölge hastanesi özelliğindedir. 1987 yılından bugüne 32 yıldır hizmet vermektedir [2]. Hastaneler, büyüklüklerine göre yatak sayısı ölçütüne göre sınıflandırıldıklarında 4 gruba ayrılmış oldukları görülmektedir.

a. En küçük hastaneler (50 yatağa kadar)

b. Küçük hastaneler (150 yatağa kadar)

c. Normal hastaneler (600 yatağa kadar)

d. Büyük hastaneler (1000 yatağa kadar) [3].

Balcalı Hastanesi bu sınıflama içerisinde büyük hastaneler grubunda yer almaktadır. Bu büyüklük içerisinde teknik ve destek hizmet birimlerinin ne kadar alan kapladığı ise araştırmanın çıkış noktasını oluşturmuştur. Şekil 1'de hastane yerleşim alanında bulunan yapıların isimleri ve konumları gösterilmiştir. Bu doğrultuda teknik ve destek hizmet birimleri belirlenerek hastane içerisindeki konumları gösterilmiştir.

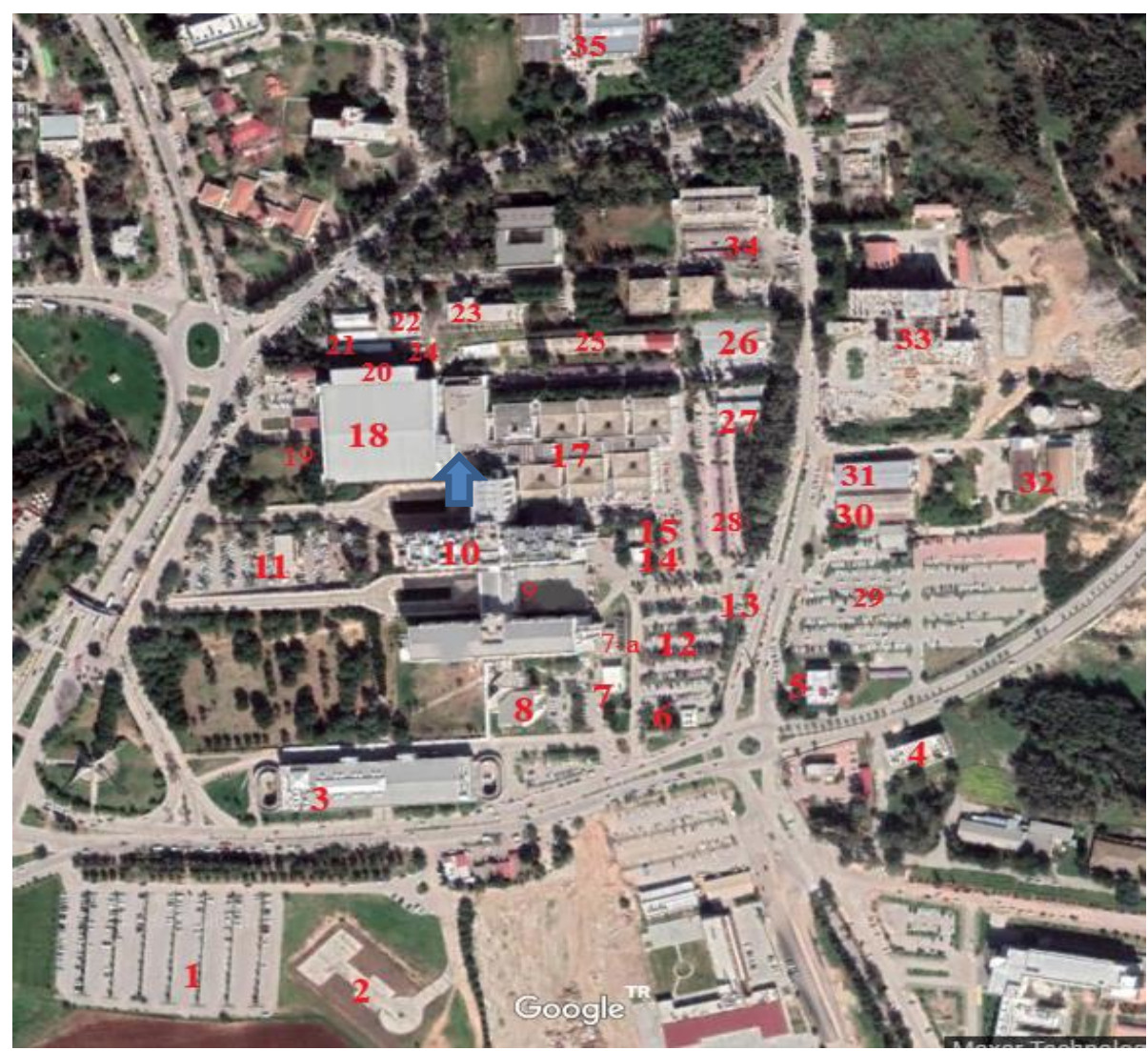

Şekil 1. Çukurova Üniversitesi Tıp Fakültesi Balcalı Hastanesi yerleşim planı 
Hastane Yapıları Teknik ve Destek Hizmet Birimlerinin Mekânsal Büyüklük Analizi: Çukurova Üniversitesi Tıp Fakültesi Balcalı Hastanesi Örneği

Şekil 1'de sağlık yapılarının ve çevresinin vaziyet planındaki konumlarına yer verilmiştir.

1. Hasta Otopark1

2. Hastane Helikopter Pisti

3. İdari Blok- Eczane sarf malzeme deposu

4. Tropikal Hastalıklar Merkezi

5. Duyma Engelliler Merkezi

6. Hastane Trafo Binasi

7. Hastane Tibbi Atık Deposu

7.a. Hastane Su Kuleleri

8. Hipokrat Amfi

9. K1 Blok-Mutfak/Yemekhane

Elektrik ve Tesisat İşleri

Medikal Gaz Odası

10. Çamaşırhane- Merkezi Sterilizasyon Birimi Y1-Y2 Blok

11. Viyadük Kafe

12. Personel Otopark

13. Hastane Şoförler Binası

14. Hastane Güvenlik

15. Hastane Çöp Deposu

16. Hastane Nizamiye

17. Poliklinikler

18. Ana Bina (A, P bloklar, Y bloklar, K bloklar)

19. Klima ve Havalandırma Santralleri

20. Klima ve Havalandırma Santralleri

21. Hastane Trafo Binas1

22. Kalite Yönetim Birimi

23. Halk Sağlığı Binası

24. Hastane Klima ve Havalandırma Santralleri

25. Arşiv Binası

26. Radyasyon Onkoloji Binasi

27. Nükleer Tıp Binası

28. Personel Otopark

29. Hasta Otopark

30. Çamaşırhane

31. Sarf Malzeme Deposu

32. Hastane Is1 Merkezi

33. Onkoloji Merkezi İnşaatı

34. Hemotoloji Laboratuar- Çocuk. Psikiyatri Binas1

35. Ç.Ü Tıp Fakültesi Binası

Hastanenin konumu ve yakın çevresi ile olan ilişkisi kısaca özetlenecek olursa;

- Hastane yapıları kuzey-güney yönünde konumlanmıştır.
- Hastane otoparkları, hasta, ziyaretçi ve idari personel olarak ayrılmıştır.

- Hastane yapısı blok sistem planlaması temel alınarak inşa edilmiştir.

- Hastane yapısının yer aldığı arazinin eğimli olmasından dolayı, kot farkı doğu ve batı girişlerinin düzenlenmesinde etkin rol oynamıştır.

- Blok sistem planlaması dışında sağlık kampüsü alanına sonradan eklenen binalar bu sistem dışında tekil olarak inşa edilmişlerdir. (Radyasyon onkoloji binası, Nükleer tıp binası, Çamaşırhane binası, Arşiv binası, Depo binaları, Ana 1s1 merkezi binas1, Ek idari bina, Onkoloji binası, olarak yer almaktadır).

- Hastane blok sistemli binalar arası köprü ile birbirine bağlanmaktadır.

- Hastane bodrum katına (doğu yönünde) araç ulaşımı sağlanarak, mutfak servis girişi bodrum kotunda çözümlenmiştir.

- Morg ve otopsi birimlerine ulaşım için ayrı giriş (doğu yönünde) verilerek hastaneye gelen dış hasta, ziyaretçi ve personelin görmeyeceği şekilde hastanenin bodrum katında düzenlenmiştir.

Hastanelerde 20-30 y1l öncesine kadar büyüklükleri yeterli görülen bazı bölümlerin, artık yeterli olmadığı, geçmişte ihtiyaç duyulan bazı alanların günümüz şartlarında kullanımının daha az olduğu, fakat yeni ve farklı özellikteki alanlara ve altyapıya ihtiyaç duyulduğu görülmektedir. Çukurova Üniversitesi Tıp Fakültesi Hastanesi de yıllar içerisinde bu mekânsal ve altyapı ihtiyaçları nedeniyle değişikliğe uğramıştır.

Balcalı Hastanesi içerisinde yeni alan ihtiyacının doğması nedeniyle bazı mekânsal değişikliklere gidilmiştir. Planlanan ek teknik birim faaliyetlerinin bazıları tamamlanarak uygulamaya geçirilmiş, bazıları ise planlama aşamasında (ihale planlama-bütçe planlama gibi) devam etmektedir.

Çamaşırhane biriminin ana binanın dışına yeni binaya taşınması ile onkoloji hastanesine de hizmet edeceği düşünülerek her iki binanın komşuluğunda yer seçimi yapılmış olduğu görülmektedir. 
Ana binadaki mevcut çamaşırhane alanına ise kemoterapi ünitesi ve eczanenin taşınması planlanmıştır. Yeni yapılan ameliyathane bölümü ve yapılması planlanan merkezi laboratuar ve yoğun bakım bölümlerine hizmet edecek olan ek çelik binanın yapımı tamamlanmıştır (klima ve havalandırma santralleri için) Yapımı planlanan merkez laboratuar projesi içerisinde bu bölüme hizmet edecek elektrik odası içinde yeni yer planlanmıştır. 2017 sonrası için teknik hizmet bölümü için yapılan ve yapımı planlanan alanların mekânsal büyüklükleri aşağıda verilmiştir.

\section{METOT}

$\mathrm{Bu}$ çalışmaya literatür taraması ile başlamıştır. Literatürde hastane yapıları içerisinde teknik ve destek hizmet birimlerinin neler olduğu tespit edilmiştir. $\mathrm{Bu}$ birimler ile ilgili hizmet alanları kısaca tanımlandıktan sonra alan çalışmasına geçilmiştir.

Alan çalışmasında öncelikle inceleme alanlarına ait planlara, kararlara, görüşmelere, gözleme ve görsel kaynaklara dayalı nitel veriler (hastane mimari planı içerisinde yer alan teknik hizmet birimlerinin konum tespitleri ile birimler arası işleyişlerinin tespiti için yerinde yapılan gözleme dayalı bulguları içermektedir) belirlenmiş, daha sonra teknik ve destek hizmet birimlerinin nicel (mekânsal büyüklüğün alansal olarak ifadesini içermektedir) olarak mekânsal büyüklükleri tespit edilmiştir. Tespiti yapılan veriler analiz ve sentez metodu kullanılarak değerlendirilmiştir. Çalışma alanı olan Balcalı Hastanesi'nde teknik ve destek birimlere ait verilerin elde edilmesinde izlenen adımlara ilişkin akış şeması Şekil 2'de gösterilmektedir. Elde edilen veriler ile çalışmada izlenen adımlara ilişkin akış şeması aşağıdaki tabloda gösterilmektedir.

Bu çalışmada Çukurova Üniversitesi Tıp Fakültesi Balcalı Hastanesi Teknik ve Destek hizmet birimlerinin mekânsal büyüklükleri ile hastanenin toplam mekânsal büyüklüğü nicel yöntemlerle hesaplanarak ilgili veriler değerlendirilmiştir. Çalışmada uygulanan adımların akış şeması Şekil 2'de yer almaktadır.
1. Hastane yapıları teknik ve destek birimlerine ait literatür taramas

2. Teknik ve destek birimlere ait nitel verilerin belirlenmesi

3. Hastane mimari projelerinin elde edilmesi

4. Hastane mimari projelerin yerinde güncel durumunun kontrol edilmesi

5. Mimari plan üzerinde teknik ve destek birimlerinin yer tespitinin yapılması

6. Balcalı hastanesi binalarının toplam kapalı alan mekânsal büyüklüklerinin hesaplanması

7. Teknik ve destek birimlerinin mimari kat planlarındaki konumlarına göre mekânsal - büyüklüklerinin hesaplanması

8. Teknik ve destek birimlerinin, hastane toplam kapalı alanının yüzde kaçını oluşturduğunun tespit edilmesi

Şekil 2. Çalışmanın yönteminin akış şeması

\section{BULGULAR}

Hastane yapıları Ak ve Akar [5] tarafindan; "sağlık hizmet üretimi yapan bir işletme çeșidi" olarak tanımlanmıştır. Bu işletmenin her bir birimi farklı nitelikler taşımaktadır. Farklı mekân işlevleri ve düzenleri gerektiren, çeşitli ekipman, teknik donanımlar ile tıbbi teknolojik bölümlerden oluşmaktadır. Hastane yapılarındaki bu bölümler, işlevlerine göre dört ana başlık altında gruplandırılmıştır [6]. Bunlar;

- Diş hasta bölümü,

- Ortak bölümler (Destek Hizmetler)

- İç hasta bölümü,

-Teknik hizmetler bölümleridir.

Dört ana başlık altında gruplanan hastane bölümleri de farklı alt birimlerden oluşmakta ve hastanenin işleyişine hizmet ederek sağllk hizmetinin gerçekleşmesine öncülük etmektedir (Şekil 3.). 
Hastane Yapıları Teknik ve Destek Hizmet Birimlerinin Mekânsal Büyüklük Analizi: Çukurova Üniversitesi Tıp Fakültesi Balcalı Hastanesi Örneği

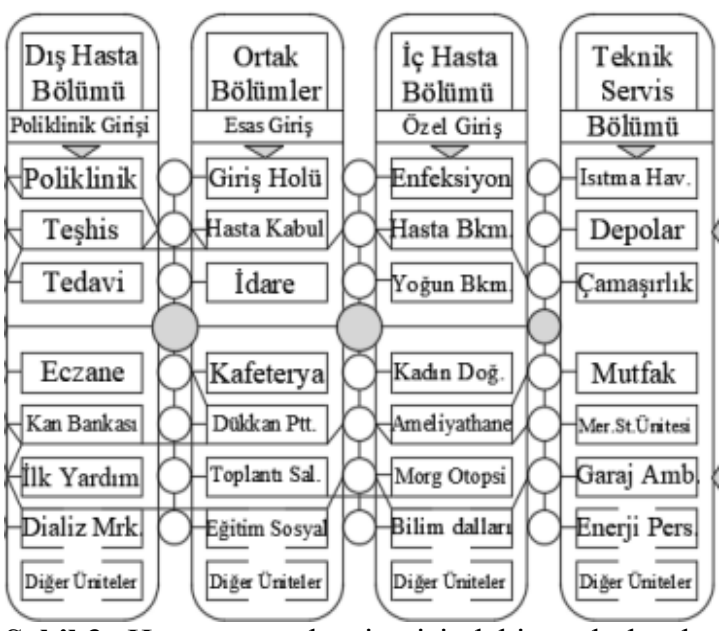

Şekil 3. Hastane yapıları içerisindeki ana bölümler ve işlevleri [7]

Çalışmaya konu olan Destek hizmet (ortak bölümler) ve Teknik hizmet birimleri Balcalı Hastanesi içerisinde incelendiğinde bu birimlerin, Çizelge 1'deki gibi alt gruplara ayrılmış olduğu görülmektedir.

Çizelge 1. Teknik ve destek hizmet alt birimleri

\begin{tabular}{|l|l|}
\hline $\begin{array}{l}\text { Teknik hizmet alt } \\
\text { birimleri }\end{array}$ & $\begin{array}{l}\text { Destek hizmet alt } \\
\text { birimleri }\end{array}$ \\
\hline Elektrik sistem odas1 & Mutfak/Yemekhane \\
\hline Mekanik sistem odas1 & Çamaşırhane \\
\hline Atık odası & Sterilizasyon Birimi \\
\hline $\begin{array}{l}\text { Merkezi gaz sistem } \\
\text { odası }\end{array}$ & Eczane \\
\hline & Arşiv \\
\hline & Güvenlik \\
\hline & $\begin{array}{l}\text { Morg/otopsi işlem } \\
\text { birimi }\end{array}$ \\
\hline
\end{tabular}

Hastanelerin işleyişinin aksamadan sürdürülebilmesi için bu alt gruplar büyük öneme sahip alanlar olarak karşımıza çıkmaktadır. Yapı ya da yap1 grupları içerisinde yer alan teknik ve destek hizmet birimlerinin tasarımı belirleyen ölçütleri ve önem dereceleri farklılaşabilmektedir. $\mathrm{Bu}$ nedenle öncelikle bu birimlerin ve ilişkide olduğu alt grupların amacını ve gereksinmelerini doğru tespit etmek ve tanımlamak önem taşımaktadır [10]. Bu doğrultuda teknik ve destek hizmet birimlerinin alt gruplarının tanımlanması ve işlevlerinin belirlenmesi gerekmektedir.

\subsection{Hastanelerde Teknik ve Destek Hizmet Birimleri}

Hastane yapılarının ana 4 bölümünden olan teknik ve destek hizmetler bölümü hastanenin diğer tüm bölümlerine hizmet sağlamaktadır. Çalışmanın bu bölümü, teknik ve destek hizmet birimlerinin hastane içerisindeki görevleri ile Balcalı Hastanesi içerisindeki durumunun değerlendirilmesini kapsamaktadır.

\subsubsection{Merkezi Sterilizasyon Birimi}

Sterilizasyon birimi hastaneye teknik ve servis hizmetlerinin verildiği bölümlerdir. Merkezi sterilizasyon ünitesinin birimlerde kullanılan malzemelerin sterilize edilmesi, paketlenip setler halinde yeniden kullanılmasina olanak sağlamaktadır. $\mathrm{Bu}$ birimler, poliklinikler, laboratuarlar, ameliyathane, yoğun bakım birimleri, doğumhane, endoskopi ve yeni doğan tedavi birimlerine yönelik aletlerin sterilizasyon işlemlerini 365 gün 24 saat aralıksız olarak yapmaktadir [6].

Balcalı Hastanesi merkezi sterilizasyon biriminin çamaşırhane ile birincil ilişkide olması gerekmektedir. 2019 öncesine kadar çamaşırhane ile sterilizasyon ünitesi asansör bağlantısı ile düşeyde birincil ilişkide, bina içerisinde bulunurken, yeni yapılan çamaşırhane alanının ana bina dışına alınması ile bu bağlantının kesintiye uğrayarak ikincil ilişkide olduğu görülmüştür.

\subsubsection{Mutfak}

Hastane mutfağı en az üç öğün olmak üzere hasta, personel ve refakatçilere yemek hizmeti vermektedir. Ayrıca, tedaviye yönelik beslenmesi gereken özel hastalar içinde yemek hazırlama işlemi mutfak biriminde yapılmaktadır Hastane tasarımlarında mutfakla ilgili olarak mutfağın hasta bakım üniteleri ile bağlantısı, mekânsal büyüklüğü, teknik gereksinimlerinin doğru düzenlenmesine dikkat edilmesi gerekmektedir [12].

Hastalara yemek servisi, servis ve monşarj asansörleri ile iletilmektedir. Hasta bakım 
ünitelerinden gelen bulaşıklar ise asansörler ile mutfak içerisinde yer alan bulaşık birimine iletilmektedir. İyi tasarlanmış bir hastane projesinde, mutfağı meydana getiren bölümlerin doğru ölçülendirilmesi ve düzgün bir şekilde düzenlenmesi yemek servisinin sorunsuz bir şekilde yapılmasını sağlayacaktır. Dolayısıyla hastane mutfağı tasarımında mekanların boyutları ve mekanlar arası organizasyonlar önem kazanmaktadır [13]. Uzunay [11] çalışmada bir hastanede mutfak için gerekli alanı hasta başına $1,5 \mathrm{~m}^{2}$ olacak şekilde değerlendirilmesi gerektiğini belirtmiştir. [14].

$\mathrm{Bu}$ doğrultuda Balcalı Hastanesi Mutfak birimi değerlendirildiğinde, hastane binasının yapım yılından itibaren mutfak alanında yer değişikliği yapılmadığı görülmüştür. Mutfak birimi ana bina içerisinde bodrum katta (K2 blok-0. Kat) yer almaktadır. Yemekhane birimi ise zemin katta yer almakta ve mutfak birimi ile düşeyde mönşarj asansör ve merdiven aracılığıyla bağlantı sağlamaktadır. Yemekler yataklı servislere yakın noktada bulunan ortak kullanılan asansörü ile bağlantılı olarak hizmet vermektedir. Mevcut mutfak birimi yaklaşık $1350 \mathrm{~m}^{2}$ 'dir. Uzunay' in belirlemiş olduğu standarda göre 1200 yatak kapasiteli bir hastane için $1800 \quad \mathrm{~m}^{2}$ mekân büyüklüğünün olması gerekmektedir.

\subsection{3. Çamaşırhane}

Çamaşırhane birimi Hastanede enfeksiyon kontrolünü sağlamak amacıyla hijyenik bir ortam oluşturmak amacıyla kullanılan tüm tekstil ürünlerini uygun şartlarda toplanmak, taşımak, yıkamak, teslimini ve imhasını sağlamak için oluşturulmuş alanlar olarak değerlendirilmektedir [11].

Enfeksiyon kontrollerinin sağlanması amacıyla, çamaşırhanelerin yapı elemanlarıyla ayrılmış kirli ve temiz çamaşır bölümü olarak ayrı tasarlanması gerekmektedir.

Balcalı Hastanesi ana bina içerisindeki eski çamaşırhane biriminde (Y1-Y2 -Y3 Blok) temiz ve kirli alanların ayrılmamış olması nedeniyle birimin enfeksiyon kontrolünün sağlanması amacıyla yenilenmesine ihtiyaç duyulmuştur. Ayrıca hastane içerisinde duyulan ek alan ihtiyacı, çamaşırhanenin onkoloji hastanesi ile olan ilişkisinin güçlendirilmesi de düşünülerek çamaşırhane birimi, ana binanın dışarısına alınmıştır. Daha önce ana binada $1000 \mathrm{~m}^{2}$ kullanım alanında olan birim, iyi bir planlama ile $870 \mathrm{~m}^{2}$, ye düşürülerek yeni binada hizmet vermeye başlamıştır. Hastane bölümler arası ilişki matrisine göre Balcalı Hastanesi Çamaşırhane biriminin sterilizasyon ünitesi ile olan birincil ilişkisi kesintiye uğradığı görülmektedir.

\subsubsection{Mekanik Sistem Odası}

Yapı içindeki havanın temizlenmesi, 1sıtılması ve soğutulması ve hijyen koşullarının tam olarak sağlanabilmesi bakımından iklimlendirmenin ve alt yapısının sağlanması gerekmektedir.

Hastanelerin 1sitılması merkezi sistemle olmalı ve 1sitma sistemi bodrum katta konumlandırılmalıdır. Fakat yatak sayısı fazla olan hastanelerde 1sitma birimi yapı dışına alınabilmektedir [14]. Gelişen teknolojiyle birlikte yeni yapılan hastanelerde tesisat katı tasarımı yapılarak ayrı bir kat olarak da uygulanmakta olduğu görülür.

Steril ortam yaratmada, hastanelerin belirli bölümlerin havalandırma ve klima sistemlerinin sistemin bütününden ayrılmasında, hasta ve çalışanların ısıl konfor şartlarının sağlanabilmesi için 1sıtma ve soğutma işlemlerine ihtiyaç duyulmaktadır. İklimlendirme ve havalandırma ameliyathanelerde, kadın doğum ünitesinde, yanık ünitelerinde, enfeksiyon bölümünde, nakil ünitelerinde, izolasyon odalarında, yoğun bakım ünitelerinde ve yeni doğan ünitelerinde ve benzeri birimlerde steril ortamlar sağlanması gerekmektedir [6].

Balcalı Hastanesi klima ve havalandırma santralleri 2017 öncesinde $1280 \mathrm{~m}^{2}$ alan kaplarken, hastanenin değişen ihtiyaçları doğrultusunda eklenen yeni mekânların iklimlendirme ve havalandırma ihtiyaçlarındaki değişim nedeniyle mekânsal büyüklüğü $2650 \mathrm{~m}^{2}$ ye çıkmıştır. İlk tasarım aşamasında bina içerisinde kurgulanan bu 
alan, hastanenin büyümesiyle birlikte bina dışında uygulanmış olduğu görülmüştür.

\subsubsection{Elektrik Sistem Odası}

Hastaneler kesintisiz enerji kaynağına sahip olmalıdır. Acil ünitesi, yoğun bakım ünitesi ameliyathaneler ve bazı dal hastanelerinin önemli bölümleri jeneratör ile desteklenmeli trafo ve ana tablo sistemleriyle hastanenin elektrik ihtiyacı sağlanmalıdır. Temiz suyun binaya kesintisiz sağlanması atık suyun deşarj edilmesi, su kesintilerine karşı suyun depolanması da tesisat ile ilgili gereklilikler arasındadır. Hastane sistemi yoğun ve kesintisiz elektrik işleyişine sahiptir. Tesisat sistemleri çıkabilecek yangın olayına karşın yangın söndürme hatları ve hastane içine yerleştirilen yangın sprinkleri ile korunmalıdır. Kimyasal atık depolanması ve deşarjlarının sağlık standartlarına uygun olarak sağlanması gerekmektedir [6].

Balcalı Hastanesi elektrik ve tesisat işleri için ayırılan mekân 2017 öncesinde $400 \mathrm{~m}^{2}$ alan kaplarken, hastanenin değiş̧en ihtiyaçları doğrultusunda eklenen yeni mekânların elektrik ve tesisat altyapı ihtiyaçlarındaki değişim nedeniyle

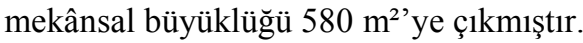

\subsubsection{Medikal Gaz Sistem Odası}

Büyük kapasiteli hastanelerde likit oksijen tank1 tesis edilerek içeride 5-10 adet oksijen tüp bulundurulmalıdır. Medikal gaz merkezlerinin bulunduğu odaların bir duvarı, doğal hava sirkülasyonunu sağlayacak, ancak çevre güvenliğine zarar vermeyecek şekilde dış ortamla ilişkide olmalıdır [6].

Balcalı Hastanesinde medikal gaz odası bodrum katta (K1 Blok) yer almakta, dış mekân ile doğrudan bağlantısı bulunmaktadır.

\subsubsection{Arşiv}

Adli vaka dosyaları, hastane personeliyle ilgili dosyalar, hasta dosyaları ve bunun gibi ilgili dökümanların tutulduğu yangında öncelikli korunacak mahaller arasında yer almaktadır.
Balcalı Hastanesi'nde Blok sitemli yapılmış ana bina grubunun kuzey kesiminde yer almaktadır. Arşiv yapısı 2019 yılı öncesinde yaklaşı $1400 \mathrm{~m}^{2}$ alanda hizmet verirken, ihtiyacın artması nedeniyle $750 \mathrm{~m}^{2}$ alan eklenerek (yatayda büyümeyle) yaklaşık $2150 \mathrm{~m}^{2}$ alanda hizmet vermektedir. Aynı zamanda yeni eklenen alan ihtiyacı dahilinde yapılan tadilat ile yapının yangın söndürme sistemi de güncel ihtiyaçları doğrultusunda yenilenmiştir.

\subsubsection{Güvenlik}

Hastaların, personelin ve ziyaretçilerin güvenliği için görevlendirilmiş kişilerin konumlandıkları stratejik alanlar olarak tanımlanabilir.

Balcalı Hastanesi ana blok yapısı kuzeyinde merkezi polis noktası olarak, bina içerisinde ise zemin katta K2 blok içerisinde güvenlik yönetim alanı bulunmaktadır. Bina içerisinde hareketli denetim noktaları ise, acil giriş noktası, Y1-Y2-Y3 yataklı servis giriş-çıkış noktaları- K2 Blok giriş çıkış noktası (Batı Cephe), Batı Cephe Personel Otopark, Morg, Mutfak giriş çıkış noktaları, Başhekimlik giriş-çıkış noktası-Ameliyathane ve Reanimasyon önü gibi çeşitli noktalarda güvenlik personelinin konumlandıkları görülmektedir.

\subsubsection{Morg/Otopsi İşlemleri}

Morg, hastanede veya dışarıda ölen kişilerin cesetlerinin ailelerine ya da görevli kişilere teslim edilmesi için bekletilen mahaller olarak tanımlanabilir. Morgun bulunduğu alan, acil servis, poliklinik, ameliyathane, yoğun bakım, servisler, laboratuar ve görüntüleme alanlarından bağımsız bir yerde konumlandırılmalıdır [8].

Balcalı Hastanesi'nde Morg ve Otopsi işlemeleri Y1-Y2-Y3 Bloğu Bodrum katta yer almaktadır. Bina dıșından hastanenin doğu cephesinden ulaşım sağlanabilmektedir. Morgun hastanenin diğer tüm birimleriyle iç bağlantısı mevcuttur.

\subsubsection{Atık Odası}

Hastanenin her türlü atıklarının insan sağlığı ve güvenliğini koruyarak, atık kategorilerine göre tasniflendiği alanlar olarak tanımlanabilir. 
Balcalı Hastanesinde hem bina içerisinde hem de bina dışında atık yönetmeliği çerçevesinde çeşitli noktalarda atık odaları yer almaktadır.

\subsubsection{Eczane}

İlaçların dağıtılması için gerekli düzenlemelerin yapıldığı yerler olarak tanımlanabilir. Dağıtım işlemi, ilaç hazırlama odasından veya ünitesinden, müstakil bir ilaç dağıtım ünitesinden veya başka onaylı bir sistem tarafından gerçekleştirilebilir. İlaç ana dağıtımının yapıldığı mekâna ek olarak depo alanları ile ayrı bir mekânda saklanması gereken parlayıcı madde niteliğinde olan alkolün, narkotik bazı ilaçların ve dışarıdan gelebilecek distile suyun saklanmasına olanak sağlayacak mahallerden oluşmaktadır [9].

Balcalı Hastanesi ana blok yapısı içerisinde zemin kat, 1 . Kat ve 3 . Kat içerisinde eczane dağıtım ve depo alanları ile ve ek bina içerisinde eczane depo alanları bulunmaktadır.

Hastanelerde Teknik ve Destek Hizmet Birimleri genel olarak tanıtıldıktan sonra Balcalı Hastanesi'ndeki bu birimlerin mekânsal büyüklükleri aşağıda değerlendirilmiştir.

\subsubsection{Depo}

Hastanelerde bölüm ve birimlerin ihtiyaçlarına göre çok çeşitli depo alanları bulunmaktadır. Depo bölümlerinde tıbbi malzeme, kimyasal malzeme, ilaç, kırtasiye malzemeleri, kuru ve yaş yiyecek, sarf malzeme, tekstil ürünleri gibi malzemeler bulunmaktadır. Balcalı hastanesinde ana bloklar ve ek bina içerisinde ve bina dışı alanlarda yer almak üzere farklı depo alanları bulunmaktadır.

\subsection{Teknik ve Destek Hizmet Birimlerinin Mekânsal Büyüklük Analizi}

Teknik ve destek hizmet birimleri alt gruplarının hastaneye vermekte oldukları hizmetin tanımları yapıldıktan sonra bu alanlarla ilgili mekânsal büyüklüklerin tespitinin yapılması, sağlık yapıları kapalı alanlarının tüm hastane bazında mekânsal büyüklüklerinin olușturulması gerekmketedir. $\mathrm{Bu}$ doğrultuda Çizelge 2'de kampüs içi sağlık yapılarının kapalı alan mekânsal büyüklükleri $190651 \mathrm{~m}^{2}$ olarak hesaplanmıştır.

Çizelge 2. Balcalı kampüs içi sağlık yapılarının kapalı alan mekânsal büyüklükleri

\begin{tabular}{|l|r|}
\hline Kampus İçi Sağlık Yapıları & Alan $\left.\mathbf{( m}^{\mathbf{2}}\right)$ \\
\hline Hastane Kafeterya & 422 \\
\hline Viyadük Cafe & 289 \\
\hline Katlı Otopark & 22012 \\
\hline Balcalı Hastanesi & 149164 \\
\hline Acil Yanı Polis Noktası & 71 \\
\hline Hastane Atık Toplama Binası & 48 \\
\hline Hastane Tıbbi Atık Depo & 75 \\
\hline Hastane Güvenlik Binası & 6 \\
\hline Şoförler Odası & 41 \\
\hline Hastane Trafo Binası & 127 \\
\hline Balcalı Hipokrat Salonu (Balcalı Ek & \\
Bina) & 2303 \\
\hline Hastane Trafo Binası & 183 \\
\hline Starbucks-Kalite Yönetim Birimi & 673 \\
\hline Hematoloji Laboratuarı & 5587 \\
\hline Çamaşırhane & 898 \\
\hline Depo & 878 \\
\hline Hastane Isı Merkezi & 1370 \\
\hline Halil Avcı Duyma Engelliler Merkezi & 780 \\
\hline Tropikal Hastalıklar Uygulama ve & \\
Araştırma Merkezi & 1145 \\
\hline Radyasyon Onkolojisi & 1001 \\
\hline Nükleer Tıp & 1445 \\
\hline Tıp Arşiv & 2133 \\
\hline Toplam m² & 190651 \\
\hline
\end{tabular}

Sağlık Bakanlığı tarafından hazırlanan, Türkiye Sağlık Yapıları Asgari Tasarım Standartları 2010 Klavuzu'da İhtisas hastaneleri asgari alan büyüklüğü yatak sayısı ile $130 \mathrm{~m}^{2}$ 'nin çapımı sonucu bulunur ifadesi yer almaktadır. Balcalı Hastanesi 1200 yataklı olup asgari alan büyüklüğünün olması gereken rakamı yaklaşık $156.000 \mathrm{~m}^{2}$ olarak belirlenmiştir. Halen yürürlükte olan imar mevzuatında yatak bașına en az $130 \mathrm{~m}^{2}$ olarak belirlenmiş olan bu büyüklük standartlarına karşın dünyada cerrahi, dahili, rehabilitasyon, psikiyatri ağırlıklı hastanelerde bu oran 150-200 m²'ye kadar çıkmaktadır.

Balcalı Hastanesi tüm branşlarda yoğun hizmet vermesi dolayısıyla yatak başına kullanılan $\mathrm{m}^{2}$ alan 
Hastane Yapıları Teknik ve Destek Hizmet Birimlerinin Mekânsal Büyüklük Analizi: Çukurova Üniversitesi Tıp Fakültesi Balcall Hastanesi Örneği

büyüklüğünün de bu çalışma ile tespit edilebileceği öngörülmektedir. $\mathrm{Bu}$ doğrultuda hastanenin toplam kapalı alan büyüklüğüne ulaşmak için, mimari planlar üzerinden yapının mekânsal büyüklükleri ölçülerek tespit edilmiştir. Tespiti yapılan metrekareler toplanarak hastanenin toplam kapalı alanı hesaplanmıştır.

Hastanenin toplam kapalı alan bilgisi elde edildikten sonra, hastanede yatak başına düşen $\mathrm{m}^{2}$ hesaplanabilmektedir.

Bu doğrultuda Balcalı Hastanesinin tüm branşlarda yoğun hizmet vermesi dolayısıyla yatak başına kullanılan $\mathrm{m}^{2}$ alan büyüklüğü de Toplam alan/Hastane yatak sayısı ile hesaplanarak $190651 / 1200=158,87 \mathrm{~m}^{2}$ olarak belirlenmiștir.

Hastanenin toplam kapalı alanı, teknik ve destek hizmet birimleri bazında değerlendirildiğinde, Çizelge 3'de gösterilen alt gruplara ayrıldıkları görülmektedir. Bunlar hastanenin yerleşim planında kat bazında değerlendirilerek mekânsal büyüklükleri sunulmaktadır.

Çizelge 3. Hastane mekânsal büyüklüklerin katlara göre dağılımları

\begin{tabular}{|l|r|}
\hline Hastane Binası Teknik ve Destek & Alan $\mathbf{( m}^{\mathbf{2}} \mathbf{}$ \\
\hline Bizmet Birimleri & \\
\hline Tesisat Odas1 & 50,12 \\
\hline Döşeme Mobilyacı Odas1 & 25,96 \\
\hline Metal Atölyesi & 98,08 \\
\hline Ambar & 78,54 \\
\hline Depo & 286,1 \\
\hline Depo & 23,31 \\
\hline Elektrik Pano Odas1 & 28,99 \\
\hline Elektrik Pano Odas1 & 21 \\
\hline Elektrik Pano Odas1 & 38,94 \\
\hline Depo & 38,94 \\
\hline Depo & 38,94 \\
\hline Kaynak Atölyesi & 11,89 \\
\hline Dinlenme Odas1 & 16,85 \\
\hline Boya Deposu & 18,93 \\
\hline Elektrik Odas1 & 70,88 \\
\hline Elektrik Odas1 & 27,91 \\
\hline Elektrik Odas1 & 29,98 \\
\hline Depo & 8,13 \\
\hline Depo & 12,49 \\
\hline Temiz Su Deposu & 31 \\
\hline
\end{tabular}

\begin{tabular}{|c|c|}
\hline Elektrik Pano Odas1 & 15,66 \\
\hline Kontrol Odas1 & 34,16 \\
\hline Mekânik Tesisat Bölümü & 1280 \\
\hline Cenaze Y1kama & 20 \\
\hline Cumhuriyet Savc1s1 & 20 \\
\hline Cenaze İşleri & 19 \\
\hline Morg & 48 \\
\hline Kantin & 78 \\
\hline Kantin & 117 \\
\hline Kuaför Bay & 18 \\
\hline Kuaför Bayan & 18 \\
\hline Toplam $\mathrm{m}^{2}$ & 2625 \\
\hline \multicolumn{2}{|l|}{ Zemin Kat } \\
\hline Kimyasal Depolama Alanı & 18,6 \\
\hline Elektrik Odas1 & 37,33 \\
\hline Yaş Sebze Deposu & 62,04 \\
\hline Yaş Sebze Deposu & 62,04 \\
\hline Kontrol O. & 40,12 \\
\hline Soğuk Oda & 10,14 \\
\hline Soğuk Oda & 8,58 \\
\hline Kompresör & 9,25 \\
\hline Soğuk Oda & 9,43 \\
\hline Soğuk Oda & 8,14 \\
\hline Soğuk Oda & 9,62 \\
\hline Diyet Mutfağ1 & 41,89 \\
\hline Et Hazırlık & 37,8 \\
\hline Sebze Hazırlık & 58,41 \\
\hline Firın & 51,04 \\
\hline Mutfak Personel Yemek S. & 34,22 \\
\hline Kazan Y1kama & 18,48 \\
\hline Bulaşık & 27,69 \\
\hline Personel Soyunma & 8,25 \\
\hline Mutfak Sorumlusu & 10,37 \\
\hline Mutfak & 37,17 \\
\hline Mutfak & 43,47 \\
\hline Günlük Depo & 18,91 \\
\hline Bilgi İşlem & 33,53 \\
\hline Trafo & 59,84 \\
\hline Güvenlik Soyunma Odas1 & 34,22 \\
\hline Temiz Çamaşır Odası & 38,19 \\
\hline Kirli Çamaşır Odası & 17,67 \\
\hline Biomedikal & 124,68 \\
\hline Biomedikal Kalbirasyon Laboratuar. & 29,79 \\
\hline Depo & 18,66 \\
\hline Biomedikal Sorumlusu & 16,46 \\
\hline Teknik Büro & 20,97 \\
\hline Sekreterlik & 18,5 \\
\hline Teknik Koordinatör & 19,6 \\
\hline Teknik Büro & 14,5 \\
\hline Oksijen Ünitesi & 28,16 \\
\hline Oksijen Ünitesi & 21,6 \\
\hline Oksijen Ünitesi & 42,72 \\
\hline
\end{tabular}




\begin{tabular}{|c|c|}
\hline Trafo Odas1 & 78,81 \\
\hline Malzeme Odas1 & 7,88 \\
\hline Elektrik İşletme Şefliği & 12,63 \\
\hline Pano Odas1 & 39 \\
\hline Soğutma Mekânik Alan & 1121,8 \\
\hline Kan Bankası & 700 \\
\hline Elektrik Pano Od. & 20 \\
\hline Su Tankı & 18 \\
\hline Eczane İlaç Dağıtım & 40 \\
\hline Eczane & 60 \\
\hline Yemekhane İdari ve Akademik & 1200 \\
\hline Özlük işleri ve İnsan Kaynakları & 45 \\
\hline Toplam $\mathrm{m}^{2}$ & 4545 \\
\hline \multicolumn{2}{|l|}{ 1. Kat } \\
\hline Güç Odas1 & 11,94 \\
\hline Havalandırma & 3,31 \\
\hline Bilgi İşlem & 12,65 \\
\hline Serum Dağıtım & 38,48 \\
\hline Eczane Dağıtım & 88,8 \\
\hline Soğuk Oda & 15,04 \\
\hline Depo & 25 \\
\hline Eczane Depo & 33,05 \\
\hline Depo & 36,15 \\
\hline Depo & 33,04 \\
\hline Depo & 69,64 \\
\hline Serum Deposu & 103,82 \\
\hline Santral Odası & 22,52 \\
\hline Server & 3,41 \\
\hline Bohçalama & 33,48 \\
\hline Depo & 11,26 \\
\hline Paketleme & 78,38 \\
\hline Ste Mer. Sorumlu Odas1 & 19,18 \\
\hline Gaz Plasma & 33,05 \\
\hline Otoklav & 29,21 \\
\hline Steril Depo & 27,08 \\
\hline Buhar & 2 \\
\hline Otomasyon Odas1 & 12,7 \\
\hline Baş Teknisyen & 12,05 \\
\hline Ecza Deposu & 55,37 \\
\hline Sterilizasyon & 32,25 \\
\hline Steril Depo & 21,46 \\
\hline Sterilizasyon Hazırlık & 30,77 \\
\hline Tesisat Odası & 7,31 \\
\hline Malzeme Odas1 & 10,6 \\
\hline Eczane & 220 \\
\hline Eczane Depo & 103 \\
\hline Eczane Depo & 220 \\
\hline Eczane Depo & 60 \\
\hline Toplam m² & 1516 \\
\hline \multicolumn{2}{|l|}{ 2. Kat } \\
\hline Otomasyon & 16 \\
\hline Toplam $\mathrm{m}^{2}$ & 16 \\
\hline
\end{tabular}

\begin{tabular}{|c|c|}
\hline 3. Kat & \\
\hline İnternet Odas1 & 8,37 \\
\hline Bilgi İşlem Odası & 8,68 \\
\hline Cihaz Deposu & 11,10 \\
\hline Asansör Mak. Dairesi & 1,85 \\
\hline Eczane \& Tibbi Malzeme Odası & 80 \\
\hline Toplam $\mathrm{m}^{2}$ & 110 \\
\hline \multicolumn{2}{|l|}{ 4. Kat } \\
\hline Sistem Odas1 & 8,37 \\
\hline Çamaşır Odası & 17,12 \\
\hline Depo & 10,8 \\
\hline Bilgi İşlem Odası & 10,71 \\
\hline Toplam $\mathrm{m}^{2}$ & 47 \\
\hline \multicolumn{2}{|l|}{ 6. Kat } \\
\hline Tesisat Odası & 5 \\
\hline Çamaşır Odası & 9 \\
\hline Çamaşır Odası & 22 \\
\hline Toplam $\mathrm{m}^{2}$ & 36 \\
\hline Bina içi teknik hizmet birimleri toplamı & 8895 \\
\hline Bina içi yaklaşık \%40 Sirkülasyon alanı & 3558 \\
\hline \multicolumn{2}{|l|}{$\begin{array}{l}\text { Ayrı Bina Olarak Tasarlanan Teknik } \\
\text { ve Destek Hizmet Yapıları }\end{array}$} \\
\hline Çamaşırhane & 898 \\
\hline Sarf Malzeme Deposu & 878 \\
\hline Trafo & 127 \\
\hline Trafo & 180 \\
\hline Trafo & 200 \\
\hline Hastane Atık Toplama Binas1 & 48 \\
\hline Hastane T1bbi Atık Depo & 75 \\
\hline Şöförler Odası & 41 \\
\hline Hastane Is1 Merkezi & 1370 \\
\hline $\begin{array}{l}\text { Klima ve Havalandırma Santralleri } \\
\text { (Genetik Böl. İçin) }\end{array}$ & 140 \\
\hline $\begin{array}{l}\text { Klima ve Havalandırma Santralleri (Yeni } \\
\text { ameliyathane, yoğun bakımlar, Merkez } \\
\text { Laboratuar. İçin) (Ek çelik bina yapıldı) }\end{array}$ & 1230 \\
\hline $\begin{array}{l}\text { Elektrik Odası (Merkez Laboratuar için- } \\
\text { ihale öncesi hazırlı sürecinde) }\end{array}$ & 180 \\
\hline $\begin{array}{l}\text { Merkezi Sterilizasyon Birimi (İhale } \\
\text { Öncesi hazırlı sürecinde) }\end{array}$ & 770 \\
\hline Arşiv depo & 2133 \\
\hline Ek bina güvenlik birimi & 7 \\
\hline Ek bina server odas1 & 22 \\
\hline Ek bina server odas1 & 15 \\
\hline Ek bina server odas1 & 15 \\
\hline Ek bina server odas1 & 12 \\
\hline Ek bina eczane serum depo & 653 \\
\hline Ek bina tıbbi sarf mlz. depo & 324 \\
\hline Ek bina ilaç depo & 307 \\
\hline Ek bina tıbbi sarf mlz. depo & 175 \\
\hline Viyadük kafeterya & 280 \\
\hline Hastane kafeterya & 420 \\
\hline
\end{tabular}


Hastane Yapıları Teknik ve Destek Hizmet Birimlerinin Mekânsal Büyüklük Analizi: Çukurova Üniversitesi Tıp Fakültesi Balcalı Hastanesi Örneği

\begin{tabular}{|l|r|}
\hline Acil yanı polis noktas1 & 71 \\
\hline Kalite Yönetim Birimi & 670 \\
\hline Kantin & 10 \\
\hline Başhekimlik & 265 \\
\hline Saymanlık Arşivi & 183 \\
\hline Çevre Denetim Birimi & 28 \\
\hline Vezne & 28 \\
\hline Muhasebe & 90 \\
\hline Defterdarlık Uzmanı & 28 \\
\hline Döner Sermaye Saymanlık & 60 \\
\hline Döner Sermaye İşletme Müd. & 90 \\
\hline Hastane Başmüdür & 28 \\
\hline Sekreter & 28 \\
\hline Hastane Müdür & 28 \\
\hline Sekreter & 28 \\
\hline Hastane Müdür Yrd. & 28 \\
\hline Sekreter & 28 \\
\hline İhale İşlem Büroları & 116 \\
\hline Sayıştay Denetçisi & 28 \\
\hline Tahakkuk Büro & 28 \\
\hline Özel Bütçe Büroları & 210 \\
\hline Hipokrat Konferans salonu & 2300 \\
\hline Toplam m & 14873 \\
\hline
\end{tabular}

Çukurova Üniversitesi Balcalı Hastanesi Sağlık Kampüsü içerisinde yer alan teknik ve destek hizmet birimleri mekânsal büyüklükleri toplanarak aşağıda Çizelge 4'de gösterilen alansal büyüklük değeri elde edilmiştir.

Çizelge 4. Çukurova Üniversitesi Balcal Hastanesi Sağlık Kampüsü içerisinde yer alan teknik ve destek hizmet birimleri mekânsal büyüklükleri toplamı

\begin{tabular}{|l|c|}
\hline $\begin{array}{c}\text { Teknik ve Destek Hizmet } \\
\text { Birimleri }\end{array}$ & $\begin{array}{c}\text { Mekânsal } \\
\text { Büyüklük }\left(\mathbf{m}^{2}\right)\end{array}$ \\
\hline Bina içi toplamı & $\mathbf{8 8 9 5}$ \\
\hline $\begin{array}{l}\text { Bina içi yaklaşık \%40 } \\
\text { sirkülasyon alanı }\end{array}$ & $\mathbf{3 5 5 8}$ \\
\hline Bina dışı birimleri toplamı & $\mathbf{1 4 8 7 3}$ \\
\hline Toplam $\mathbf{~ m}^{\mathbf{2}}$ & $\mathbf{2 7 3 2 6}$ \\
\hline
\end{tabular}

$27326 \mathrm{~m}^{2}$ toplam alanın $8895 \mathrm{~m}^{2}$ 'si Balcalı Hastanesi A-P-Y ve K blokları içerinde yer almaktadır (Şekil 3). Bu mahallerin kullandığı bina içi sirkülasyon alanı ise $3558 \mathrm{~m}^{2}$ olarak hesaplanmıştır. Ana bina dışında yer alan teknik ve destek hizmet birimleri toplamı ise $14873 \mathrm{~m}^{2}$ olarak belirlenmiştir.
$\mathrm{Bu}$ üç alan toplandığında $27326 \mathrm{~m}^{2}$ teknik ve destek hizmet mahalleri toplam alanına ulaşılmıştır.

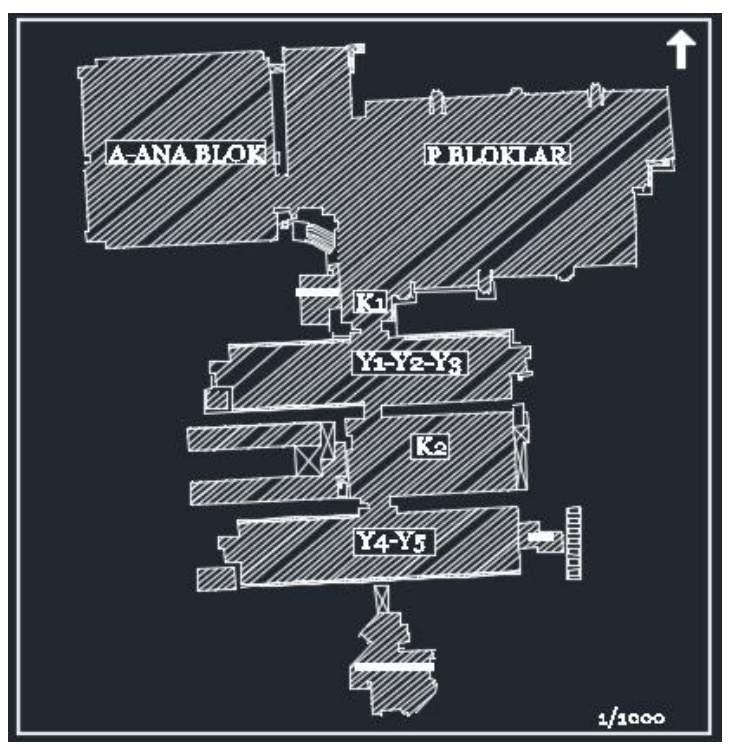

Şekil 3. Balcalı hastanesi planı blok yerleșimi

$\mathrm{Bu}$ mekânsal büyüklükleri oransal olarak değerlendirildiğinde;

- Hastanenin ana blokları olan A-P-Y ve K blokları içerisinde yer alan, teknik ve destek hizmet birimlerinin büyüklüğü yaklaşık $\% 32,5$,

- $\mathrm{Bu}$ yap1 grubunun sirkülasyon alanı büyüklüğü \%13,

- Blok yapı grubu dışında yer alan teknik ve destek hizmet birimlerinin mekânsal büyüklükleri ise $\% 54,4$ olarak belirlenmiştir (Şekil 4).

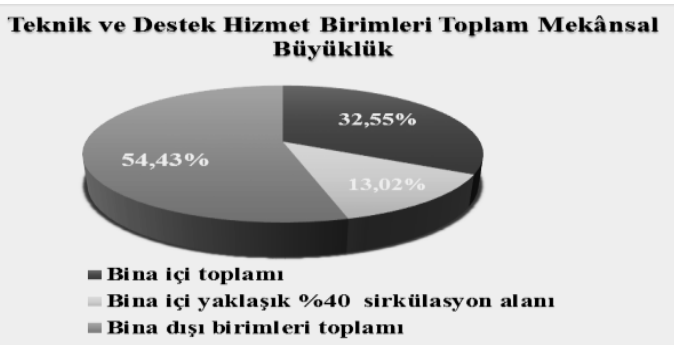

Şekil 4. Teknik ve destek hizmet birimlerinin toplam mekânsal büyüklük oranları 
Teknik ve destek birimlerin büyük oranının Balcalı Hastanesi'nin ilk yapılan ana bloğu dişında daha fazla yer kaplamasının nedeni, hastanenin yeni mekân ihtiyaçları doğrultusunda büyümesinden dolayı, teknik ve destek birimlerin ana bina dışında şekillenmeye başlamasıyla açıklanabilmektedir.

$\mathrm{Bu}$ şekillenmenin bina dışında olmasından dolayı sağlık kampüs alanı içerisindeki açık alan oranlarının düşmesine ve birtakım çevresel konfor şartlarında düşmeye neden olduğu görülmektedir. Ana blok çevresinde yer alan bu yeni teknik ve destek hizmet birimlerinin şekillenmesi birtakım problemleri de beraberinde getirmektedir. Bunlar şu şekilde sıralanabilir;

Otopark alanının azalması

> Yeşil alan kullanımının azalması

$>$ Otopark ihtiyacinın artması

$>$ Binalar arası ilişkilerde zayıflık

> Binalar arası işleyişte aksaklıklar

$>$ İş gücünde artış talebi gibi

$>$ Hastane iş akışında aksamalardır.

\section{SONUÇ VE ÖNERILER}

Hastaneler karmaşık yapılardır. Birçok fonksiyonu bünyelerinde barındırırlar. Bütün bu fonksiyonların düzgün ve tam olarak işleyebilmesi için teknik ve destek hizmet birimlerinin mekânsal büyüklüklerinin ve mekân organizasyonlarının doğru düzenlenmesi önemlidir.

Doğru mekânsal büyüklük içerisinde doğru işleyişle temizlenmemiş bir çarşaftan hastaya enfeksiyon bulaşabileceği gibi, aynı şartlar sağlanmamış bir mutfakta pişen yemek de hasta için hayati tehdit oluşturabilmektedir. Bu bakış açısıyla doğru tasarlanmamış bir iklimlendirmenin hasta enfeksiyonu için taşıyıcı özellikte olduğu, iyi düzenlenmemiş bir ameliyathane aydınlatmasının ameliyat performansını etkileyeceği, gaz sisteminde olas1 bir arızanın hastanın oksijen ihtiyacını karşılayamayacağı, otomasyonda meydana gelecek bir kesintinin tüm hastane işleyişini durdurabileceği gerçeği ile her saniyenin hasta hayatı için önemi göz önüne alındığında teknik ve destek hizmet birimlerinin hastane içindeki önemi daha iyi anlaşılabilmektedir
Çukurova Üniversitesi Tıp Fakültesi Balcalı Hastanesi; çevre düzenlemesiyle birlikte $95.000 \mathrm{~m}^{2}$ açık alan üzerine kurulmuştur. Hastane toplam kapalı alanları yaklaşık $190.651 \quad \mathrm{~m}^{2}$ den oluşmaktadır. Günümüz kullanımında Teknik ve Destek hizmet birimlerinin mekânsal büyüklükleri toplamı $27.326 \mathrm{~m}^{2}$ olarak tespit edilmiştir. $\mathrm{Bu}$ doğrultuda Hastanesi'nin toplam kapalı alan büyüklüğünün yaklaşık olarak \%14,3'ünü Teknik ve Destek hizmet bölümlerinin oluşturduğu görülmüştür (Şekil 5).

Hastane Teknik ve Destek Hizmet Birimlerinin Hastanenin Diğer Birimlerine Oranı

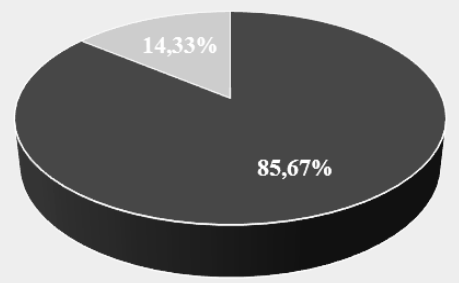

- Hastane diğer birimler $\quad$ Teknik ve Destek Hizmet Birimleri

Sekil 5. Hastane teknik ve destek birimlerinin diğer birimlere oranı

$\mathrm{Bu}$ çalışma ile hastane tasarımlarında ön planda tutulan mimari konfor şartlarının ve estetik düzeyin yanısıra, sisteme can veren teknik ve destek hizmet bölümlerinin önemine dikkat çekmek istenmiștir. Böylesi büyük bir yüzde oranını kapsayan alanların tasarımlarının da, binanın estetik yönü kadar önemle kurgulanması gerekmektedir. Zira bu alanların doğru yerde, doğru ilişkide, doğru mekânsal büyüklük ile sağlık standartları ve ilgili yönetmelikler çerçevesinde tasarlanması, hastane yapılarının mekânsal konfor düzeylerinin artması ve sağl1k hizmetinin aksamadan yürütülmesinde birincil öneme sahip alanlar olarak karşımıza çıkmaktadır. Böylece Hastanelerin, mimari anlamda yapı olduğu ancak tesisat mühendisliği yönünden; yapının ötesinde, tesisat uygulamalarının önem kazandığı, teknik ve destek hizmetler olmadan varlıklarını sürdüremeyecek olan yapılar olarak değerlendirilmeleri gerekliliği sonucuna varılmaktadır. 
Bu bağlamda incelenen hastane örneğinde, teknik ve destek hizmet bölümlerinin toplam yap1 alanının \%14,3 gibi ciddi bir mekânsal büyüklüğü oluşturması, hastane yapılarının, mimari bir yapı olma özelliği yanında tesisat mühendisliği gerektiren, özel uzmanlık isteyen tasarım alanı grubunda yer alması gerekliliği, mekânsal büyüklük üzerinden vurgulamaktadır.

Ayrıca hastane ve çevresinde yer alan, teknik ve destek hacimlerin diğer birimlerle olan etkileşiminin de hastane yapılarının tasarımında büyük öneme sahip olduğu ve tasarlanacak yeni hastane yapılarında multidisipliner bir çalışmanın gerekliliği öngörülmektedir. Hastane yapılarının her bir biriminin işlevsel, teknolojik, ekonomik ve estetik uygunluk ölçütlerine göre, ayrı ayrı düşünülerek tasarlanması gerekmektedir.

\section{KAYNAKLAR}

1. Harputlugil, T., 2005. Yap1 Elde Etme Sürecinde Tasarım Yönetimi-Hastane Yapılarının

2. Çukurova Üniversitesi, Genel Bilgi. https://www.cu.edu.tr/cu/institutional/universit y/genel-bilgi. (Erişim: 27.09.2019)

3. Kavuncubaşı, Ş., 2000. Hastane ve Sağlık Kurumları Yönetimi, Ankara: Siyasal Kitabevi.

4. Google earth hava fotoğrafi. https://earth.google.com/web/ (Erişim: 25.09.2019)

5. Ak, B., Akar, Ç. 1987. Hastane Kavramı, Sağlık Yönetimi, Yıl: 1 Ekim, Sayı: 3-4.

6. Görken, S., 2018. Genel Hastanelerde İç-D1ş Yerleşime Bağlı Bölümler Arası İlişkilerin İncelenmesi Fen Bilimleri Enstitüsü, Yakın Doğu Üniversitesi.

7. Arcan, E.F., 1983. Sağlık Merkezlerinin Planlanmasina Esas Olacak Verilerin Belirlenmesi için Bir Yöntem ve Bu Konuda Bilgi Bankası Oluşturulması, DGSA Yayınlanmamış Doktora Tezi-İstanbul.

8. T.C. Sağlık Bakanlığ İnşaat ve Onarım Daire Başkanlığı, 2010 Türkiye Sağlık Yapıları Asgari Tasarım Standartları $2010 \quad$ Y1l Kilavuzu, Ankara.
9. Tepe İnşaat Grubu, 1998. Mersin Üniversitesi Tıp Fakültesi 300 Yataklı Eğitim ve Uygulama Hastanesi Fizibilite Raporu, Ankara.

10. Tipi, Ç.B., 2017. Tıp Fakültesi Hastanelerinin Erişebilirlik, Kullanışlılık ve Kullanıcı Memnuniyeti Kapsamında Değerlendirilmesine Yönelik Bir Yöntem Önerisi. Gazi Üniversitesi Fen Bilimleri Enstitüsü, Doktora Tezi, Ankara.

11. Sağlık Bakanlığı Türkiye Kamu Hastaneleri Kurumu Bursa İli Kamu Hastaneler Birliği Genel Sekreterliği Orhaneli İlçe Devlet Hastanesi, Çamaşırhane İşleyiş Prosedürü, 2013.

12. Aydın, D., 2009. Hastane Mimarisi, İlkeler ve Ölçütler. Mimarlar Odası, Konya Şubesi.

13. Yılmaz, Ç., 2012. Hastane Binalarında Yeme İçme Alanlarının Kullanıcı Memnuniyeti Açısından Değerlendirilmesi, Yüksek Lisans Tezi, İstanbul Teknik Üniversitesi, Fen Bilimleri Enstitüsü, İstanbul

14. Uzunay, S., 2011. Hastane Yapılarının Planlanması ve Hastanelerde Sirkülasyon, Yüksek Lisans Tezi, Haliç Üniversitesi, Fen Bilimleri Enstitüsü, İstanbul. 